$\begin{gathered}\text { Науковий вісник НлТУ України } \\ \text { Scientific Bulletin of UNFU } \\ \text { https://nv.nltu.edu.ua }\end{gathered}$
$\begin{gathered}\text { https://doi.org/10.36930/40290820 } \\ \text { Article received 04.10.2019 p. } \\ \text { ISSN 1994-7836 (print) }\end{gathered}$
Article accepted 31.10.2019 p.
УДк 620.198

О. Б. Гасій, М. Ф. Федина, Л. В. Салапак

Національний лісотехнічний університет Украйни, м. Львів, Украӥна

\title{
ВПЛИВ ХІМІЧНОГО СКЛАДУ РОЗЧИННИКІВ НА СТУПІНЬ ОЧИЩЕННЯ ПОВЕРХНІ ПЕРЕД НАПИЛЕННЯМ ЙОННО-ПЛАЗМОВИХ ПОКРИТТІВ
}

\begin{abstract}
Наведено результати досліджень впливу різних класів розчинників на олієвмісні забруднення на поверхні деталей із вуглецевої сталі перед нанесенням йонно-плазмових покриттів. Як розчинники використано $\mathrm{C}_{6} \mathrm{H}_{14}, \mathrm{C}_{8} \mathrm{H}_{18}, \mathrm{C}_{6} \mathrm{H}_{6}, \mathrm{CHCl}_{3}, \mathrm{CCl}_{4}$, $\mathrm{C}_{2} \mathrm{H}_{4} \mathrm{Cl}_{2}, \mathrm{C}_{2} \mathrm{H}_{5} \mathrm{OH}, \mathrm{C}_{4} \mathrm{H}_{9} \mathrm{OH}, \mathrm{C}_{2} \mathrm{H}_{5} \mathrm{OCOCH}{ }_{3}, \mathrm{NaOH}, \mathrm{HCl}$. Забруднювачами поверхні були солідол і мастильно-охолоджувальна рідина (МОР) Укрінол-4. Для зразків, оброблених солідолом, найкращий результат зафіксовано в неполярного розчинника октану $\mathrm{C}_{8} \mathrm{H}_{18} \mathrm{i}$ слабкополярного розчинника етилетаноату $\mathrm{C}_{2} \mathrm{H}_{5} \mathrm{OCOCH}_{3}$, для яких втрата маси перевищила $1 \%$. Втрату маси більше ніж 0,5 \% виявлено в неполярних розчинників і хлорозаміщених вуглеводнів. У неполярних розчинників ступінь очищення покращувався зі зростанням молярної маси розчинника та насичення Гідрогеном, а для хлорозаміщених вуглеводнів iз зростанням вмісту Хлору. Найкращі результати очищення зі спиртів виявлено в ізобутанолу $\mathrm{C}_{4} \mathrm{H}_{9} \mathrm{OH}$. Зразки, оброблені МОР Укрінол-4, відмивали розчинниками $\mathrm{CCl}_{4}, \mathrm{C}_{2} \mathrm{H}_{5} \mathrm{OH}, \mathrm{C}_{6} \mathrm{H}_{14}, \mathrm{C}_{2} \mathrm{H}_{4} \mathrm{Cl}_{2}$, що свідчить про вагомий внесок поверхнево-активних речовин (ПАР) і присадок, що присутні у складі МОР. Здатність до очищення зростає у такій послідовності: лужні та кислі водні розчини $\rightarrow$ спирти $\rightarrow$ хлорозаміщені вуглеводні $\rightarrow$ неполярні та слабкополярні розчинники. Досліджено фізико-хімічні властивості та визначено вміст сторонніх продуктів в оливах класу HLP для гідросистем i для напрямних верстатів. Проведено порівняння ІЧ-спектрів свіжої та вживаної олив. Встановлено, що в процесі роботи олива окиснюється. Найбільше процес експлуатації вплинув на зростання кислотного числа (в три рази) та вмісту води (в дев'ять разів).

Ключові слова: мінеральна олива; кальцієві мила; мастильно-охолоджувальна рідина; поверхнево-активні речовини; інфрачервоний спектр; кислотне число.
\end{abstract}

Вступ. Специфіка технології вакуумного йонноплазмового напилення полягає в тому, що на якість покриття надзвичайно великий вплив має стан поверхні деталей перед напиленням. Підвищені вимоги до чистоти поверхні відрізняють цю технологію від інших способів поверхневого зміцнення. У місцях забруднень погіршується адгезія покриття 3 основою, воно відшаровується, а це, внаслідок його малої товщини, призводить до утворення наскрізних пор, що особливо небезпечно для деталей, які працюють в агресивних середовищах (Hasiy, 2008). Фактично, процес оброблення складається 3 двох етапів: хімічного очищення поза межами вакуумної камери і розпилювання підкладки високоенергетичними потоками йонів безпосередньо в камері. 3 огляду на значний вплив стану поверхні деталі перед нанесенням покриття на його якість, актуальною $\epsilon$ проблема якомога повного усунення забруднювачів під час попереднього очищення.

Об'єктом дослідження є сторонні речовини органічного походження на поверхні деталей, що утворились у процесі механічного оброблення заготовок або під час консервації.

Предметом дослідження є такі розчинники: лужні та кислі водні розчини, спирти, хлорозаміщені вугле- водні, неполярні та слабкополярні розчинники.

Мета роботи полягає у визначенні впливу хімічного складу зазначених вище розчинників на здатність до видалення забруднень зі стальної поверхні.

Для реалізації мети роботи потрібно виконати такі основні завдання дослідження: проаналізувати наявні методи очищення поверхні; визначити оптимальні методи очищення залежно від хімічного складу забруднень; встановити вплив сторонніх речовин, світла та повітря на зміну хімічного складу та фізико-хімічних властивостей відпрацьованих олив; визначити ступінь очищення поверхні залежно від хімічного складу досліджуваних розчинників.

Огляд наявних способів очищення поверхні. Очищення застосовують для видалення 3 поверхні металу засобів консервації, забруднень, рідин, що змащують і охолоджують деталь, нерівностей поверхні, іржі, окалини, травильного шламу. Для очищення прокату, деталей і зварних вузлів застосовують механічні, фізичні та хімічні методи.

Механічно забруднення видаляють за допомогою піскоструминних, дробоструминних i дробеметних пристроїв; використовують також шліфувальні верстати, що очищають поверхню шліфувальними кругами i

Інформація про авторів:

Гасій Олександр Богданович, канд. техн. наук, доцент, кафедра технології матеріалів та машинобудування.

Email: o.hasiy@gmail.com; https://orcid.org/0000-0001-7684-710X

Федина Михайло Федорович, канд. хім. наук, доцент, завідувач кафедри хімії. Email: fmf@ua.fm

Салапак Любов Василівна, ст. викладач, кафедра технології матеріалів та машинобудування. Email: lyubov.salapak@gmail.com

Цитування за ДСТУ: Гасій О. Б., Федина М. Ф., Салапак Л. В. Вплив хімічного складу розчинників на ступінь очищення поверхні перед напиленням йонно-плазмових покриттів. Науковий вісник НЛтУ України. 2019, т. 29, № 8. С. 110-115.

Citation APA: Hasiy, O. B., Fedyna, M. F., \& Salapak, L. V. (2019). Effect of solvents chemical composition on the degree of surface cleaning before evaporation of ion-plasma coatings. Scientific Bulletin of UNFU, 29(8), 110-115. https://doi.org/10.36930/40290820 
стрічками, металевими щітками тощо (Savuliak et al., 2012). Піскоструминне очищення деталей від окалини $і$ поверхневих оксидів є універсальним і продуктивним способом, але його істотним недоліком є виділення великої кількості кварцового пороху та уламків, тому цей метод не відповідає сучасним вимогам промислової санітарії і техніки безпеки. Останнім часом деталі з різних матеріалів, окрім алюмінієвих і магнієвих сплавів, корозійностійких сталей аустенітного класу, жароміцних сталей і сплавів очищують обдуванням металевим піском, який отримують 3 чавунного дробу. Дробоструменеве і дробеметне очищення застосовують для листового прокату та зварних вузлів за товщини металу 3 мм i більше: частинки дробу розміром $0,7 \ldots 4$ мм викидають через сопло повітрям під тиском на поверхню, що очищується. У дробеметних апаратах для збільшення продуктивності дріб викидається лопатками ротора.

Фізичні методи очищення грунтуються на використанні впливу на поверхню деталі енергії, що вивільняється під час певних фізичних процесів. Зокрема до цих методів належить ультразвукове оброблення (Smirnov, 2012). Особливістю високоенергетичних ультразвукових коливань $є$ можливість фокусування енергії на порівняно невелику площу робочої зони. Поширення високоенергетичних коливань у рідких середовищах супроводжується такими ефектами, як: кавітація, акустичний потік, радіаційний тиск. Головним чинником, що руйнує забруднення, є кавітація, що призводить до утворення звукової хвилі, дрібних бульбашок (діаметром $10 \ldots 100$ мкм), заповнених парами середовища, що очищує поверхню. Після короткочасного існування $(10 \ldots 15$ мкс) частина бульбашок вибухає, створюючи локальні гідравлічні удари тиском у десятки мегапаскалей, під дією яких відбувається руйнування забруднень. Інша частина пухирців під дією акустичних потоків інтенсивно пульсує та перемішується у гідродинамічних потоках, сприяючи інтенсифікації очищення. Ефективність ультразвукового очищення характеризується питомою акустичною потужністю, частотою коливань, складом очищувального середовища.

Технологія електроімпульсного оброблення виробів $\epsilon$ екологічно чистим і замкненим процесом без шкідливих витоків (Shevchenko, Zelinskaja \& Zhupinskaja, 2009). Він відбувається у шарі холодної плазми товщиною 0,25 .. 0,5 мм, що формується на поверхні виробу з компонентів електроліту та містить йони та радикали у вільному стані. Електролітом є водний соляний розчин, що не містить солей важких металів і екологічно шкідливих компонентів. Поверхня деталі (анод) відокремлена від електроліту парогазовою оболонкою, котра виникає внаслідок інтенсивного перебігу електролітичних процесів та кипіння електроліту під дією високої напруги та значної щільності струму. Внаслідок електростатичної сили електроліт втягується у парогазову оболонку 3 утворенням мікроскопічних рідких електролітичних містків, які з'єднують поверхню деталі з поверхнею електроліту. При цьому виділяється значна кількість теплової енергії відповідно до закону Джоуля - Ленца, що призводить до "вибуху" містків і руйнування поверхні деталі під дією ударної хвилі. Окрім того, йони, які знаходяться в парогазовій оболонці, бомбардують поверхню анода 3 енергією близько 2,5...40 еВ, внаслідок чого відбувається процес розпилення поверхневих шарів, який супроводжується іскровими розрядами, що та- кож сприяє очищенню поверхні. Як електроліт використовують водний розчин $\mathrm{NaCl}$ чи $\mathrm{NH}_{4} \mathrm{Cl} 3$ концентрацією 30 г/л. Оброблення проводять за температури $20{ }^{\circ} \mathrm{C}$ і струму силою $1 \ldots 5 \mathrm{~A}$. Солі $\mathrm{NaCl}$ та $\mathrm{NH}_{4} \mathrm{Cl}$, що входять до складу електроліту, мають необмежену розчинність у воді і добре дисоціюють: $\mathrm{NaCl} \leftrightarrow \mathrm{Na}^{+}+\mathrm{Cl}^{-}$; $\mathrm{NH}_{4} \mathrm{Cl} \leftrightarrow \mathrm{NH}_{4}^{+}+\mathrm{Cl}^{-}$. Наявність в електроліті хлоридйонів $\mathrm{Cl}^{-}$позитивно впливає на руйнування оксидних плівок поверхневих шарів деталей (Shevchenko, Zelinskaja \& Zhupinskaja, 2009).

До фізичних методів також належить очищення поверхні низькотемпературною плазмою (Maksimov \& Grigorova, 2007). Аналіз дії потоку плазми на поверхню забрудненого металу дає змогу припустити, що для очищення його поверхні від органічних забруднень є можливим використання низькотемпературної плазми у межах $300 \ldots 400{ }^{\circ} \mathrm{C}$, що забезпечує граничну температуру сублімації органічних сполук. Цей спосіб очищення забезпечує випаровування або сублімування забруднень незалежно від їхнього складу завдяки високій швидкості теплового нагрівання поверхні металу потоками плазми зі щільністю $10^{2} \ldots 10^{3} \mathrm{BT} / \mathrm{cm}^{2}$. Принципово технологічний процес очищення поверхні низькотемпературною плазмою складається 3 таких етапів: 1) створення вакууму або захисної атмосфери у вакуумній камері; 2) збудження електричного розряду між одним або кількома електродами, що знаходяться у вакуумній камері; 3) переміщення катодних плям по поверхні металу за допомогою утвореного магнітного поля різної конфігурації; 4) збудження малопотужних дугових розрядів постійного струму між додатковими електродами та виробом; 5) збудження основного імпульсно-частотного розряду енергією 0,5...0,6 Дж за тиску $10^{-5} \ldots 10^{-4}$ Па.

Хімічними методами проводять знежирення і травлення поверхні. Під час штампування, волочіння, різання металу тощо на поверхні відкладаються різного роду забруднення: жири, мила і мастила. У процесі подальшого механічного оброблення, під час операцій зварювання вони згоряють і разом із частинками абразивних матеріалів заповнюють наявні на поверхні заглиблення і нерівності. З'являються й інші види забруднень, зокрема частинки сажі, що утворюються за неповного згоряння органічних речовин, міцно пристають до металевої поверхні. Хімічне очищення від жирів та інших забруднювачів виконують ванними та струменевими методами.

У першому випадку деталі певний час витримують послідовно у ваннах із різними розчинами. У другому випадку послідовно подачу розчинів різного складу на поверхню деталі проводять струменем (Vasiltsov \& Podvezenny, 2011). Цей метод дає змогу здійснювати безперервний процес очищення. У масовому і багатосерійному виробництві травлення є більш продуктивним процесом, ніж механічне очищення поверхні. Недолік його полягає в можливості перетравлення поверхні металу і в складності роботи з травильними розчинами та необхідності подальшої їхньої утилізації. Цей метод базується на здатності кислот і лугів розчиняти на поверхні оксиди, гідроксиди та солі металів. Зазвичай застосовують водні розчини кислот - сульфатної, хлоридної, нітратної, ортофосфосфатної, флуоридної - та їхні суміші, водні розчини лугів, окремих солей, наприклад $\mathrm{FeCl}_{3}$, а також газові травники. Для травлення деталей потрібне окреме приміщення, обладнане ваннами, завантажувальними пристроями, сушильними шафами, 
вентиляцією і стоками для рідин. Поверхня металів після травлення у багатьох випадках більш придатна для нанесення покриттів, ніж поверхня після механічного очищення. Застосування хімічного травлення обмежене внаслідок шкідливого його впливу та високої вартості устаткування для очищення стічних вод.

Окрім методів струменевого очищення поверхонь, дедалі частіше використовують метод очищення струменем частинок льоду та "сухого" льоду - кристалічного вуглекислого газу $\mathrm{CO}_{2}$, який не має запаху, смаку i кольору, не проводить електричний струм і не горить (ASTM E2412, 2004). Температура "сухого" льоду становить $-78,33{ }^{\circ} \mathrm{C}$. Це нешкідливий для навколишнього середовища та обслуговуючого персоналу та відносно недорогий метод очищення, який можна використовувати без демонтажу виробів і вузлів. Найчастіше у пневматичних чи електропневматичних установках використовують гранули "сухого" льоду діаметром 1,7 i 3 мм. Струменем гранул "сухого" льоду можна очищати практично будь-які поверхні залежно від ступеня їхнього забруднення за робочої температури експлуатації. Цей метод ефективний для видалення 3 поверхні бруду, олив, бензину, смол, азбесту, токсичних залишків, сажі, нагару, клеїв, фарби, зварювальних шлаків, він запобігає розвитку корозії очищених поверхонь.

Залежно від хімічного складу, забруднення металевих поверхонь поділяють на такі види (Shevchenko, Zelinskaja \& Zhupinskaja, 2009):

- органічні (антикорозійні та мастильні оливи, мінеральні оливи, вазелін, віск з нафти, парафін, жирні кислоти, каніфоль, деревні смоли тощо);

- неорганічні (оксиди, гідроксиди та солі, що відкладаються внаслідок гартування або інших операцій попереднього оброблення, нагар, металева стружка та порошки - залишки шліфування, залишки полірувальних паст тощо);

- змішані (оливи, які застосовують під час оброблення металів тиском, розчинні оливи й емульсійні композиції, до складу яких входять різні пігменти у вигляді дрібнодисперсних порошків, металічні порошки), які значно ускладнюють очищення, особливо після нагрівання.

У разі видалення забруднень 3 поверхні металів особливого значення набуває вибір найефективнішого методу очищення, який залежить від таких чинників: природи забруднення, необхідного ступеня очищення, впливу хімічних компонентів миючого розчину на металеву поверхню, найменшого шкідливого впливу на довкілля, безпеки під час роботи та вартості. Найчастіше в металообробній промисловості використовують фізикохімічні методи видалення забруднень: 1) відмивання органічними розчинниками; 2) очищення водними розчинами кислот, лугів різної концентрації та за різного температурного режиму; 3) емульсійне очищення.

Органічний розчинник утворює однорідну суміш або розчин із забрудненням. Дуже важливо, підбираючи розчинник, враховувати хімічну природу забруднення. Як розчинники використовують велику кількість речовин та їхніх сумішей: від води різної температури, кислот і лугів різної концентрації до насичених і ароматичних рідких вуглеводнів та їхніх галогенопохідних, кетонів, спиртів, етерів тощо. Зазвичай також враховують такі властивості розчинника: леткість 3 метою простішого i кращого видалення надлишку, хімічну стійкість до дії різних чинників, низький поверхневий натяг для кращого змочування поверхні металу, можливість регенерації з метою багаторазового використання.
Чиста вода виявляє слабку миючу дію для олійних i жирових забруднень, тому використовують лужні розчини 3 різним значенням $\mathrm{pH}$, однак тут обов'язковим $\epsilon$ додавання поверхнево-активних речовин (ПАР), а також емульгаторів і речовин, що підсилюють змочування поверхні. Як електроліти в миючих засобах для технічних цілей найчастіше застосовують: каустичну соду $\mathrm{NaOH}$, кальциновану соду $\mathrm{Na}_{2} \mathrm{CO}_{3}$, натрій силікати $x \mathrm{Na}_{2} \mathrm{O} \cdot y \mathrm{SiO}_{2}$, солі фосфатних кислот $\mathrm{Na}_{4} \mathrm{P}_{2} \mathrm{O}_{7}, \mathrm{Na}_{5} \mathrm{P}_{3} \mathrm{O}_{10}$, $\left(\mathrm{NaPO}_{3}\right)_{\mathrm{n}}$ і натрій сульфат $\mathrm{Na}_{2} \mathrm{SO}_{4}$.

Окрім неорганічних солей, до складу синтетичних миючих засобів входять деякі органічні продукти, що підвищують їхню якість. До них належать передусім карбоксиметилцелюлоза (КМЦ) для запобігання зворотного осідання забруднень на вже очищені поверхні. Окрім того, КМЦ збільшує миючу здатність миючих засобів. Так, наприклад, алкіларілсульфонати без додавання КМЦ гірше утримують забруднення. Якщо в процесі очищення необхідно видаляти не тільки оливу, але i тверді частинки, що знаходяться на поверхні (металевий пил, залишки після шліфування, полірувальні пасти та ін.), то проводять додаткове емульсійне очищення. Очисні суміші є емульсіями розчинника у воді зі стабілізуючими ПАР. Як органічні розчинники використовують вуглеводні та їхні хлоропохідні. 3 емульгаторів часто застосовують аміномила, нафтенати, алкіларилсульфонати, алкілсульфонати i поліоксиетиленові нейоногенні ПАР з низьким піноутворенням. До складу емульсій для очищення часто вводять спеціальні добавки (спирт, гліколеві ефіри), що підвищують взаємну розчинність i полегшують суміщення емульгатора 3 розчинником, а також інгібітори корозії.

Очищення емульсійними сумішами істотно відрізняється від очищення органічними розчинниками та лужними знежирювальними розчинами. В емульсіях одночасно з розчиненням оливних забруднень органічними розчинниками відбувається емульгування цих забруднень. Зниження в'язкості забруднень під час їхього розчинення органічними розчинниками полегшує процес емульгування, внаслідок якого краплі емульсії не забруднюють вже відмиту поверхню.

Матеріали й методи дослідження. Для того, щоб встановити різні типи сторонніх речовин і продуктів деградації оливи, які потрапили на поверхню деталі чи утворились у процесі роботи, порівнювали інфрачервоні спектри (ІЧ-спектри) свіжої та вживаної олив. Різні типи речовин можна ідентифікувати за зміною абсорбції за певних довжин хвиль. Вміст продуктів окиснення, нітрування та вміст сажі отримали за допомогою інфрачервоного Фур'є-спектрометра PerkinElmer згідно 3 методикою ASTM E2412 (DSTU HOST 33, 2003). Стандартно визначали: воду за $3500-3150 \mathrm{~m}^{-3}$, продукти окиснення 1800-1670 м $1600 \mathrm{~m}^{-3}$, продукти сульфування 1180-1120 м ношувальну присадку (ZDDP) 1025-960 м².

Визначення кінематичної в'язкості проводили 3 використанням автоматичної віскозиметричної системи LAUDA i Visc згідно з методикою ДСТУ ГОСТ 33-2003 (DSTU HOST 25371, 2006). Індекс в'язкості розраховували з використанням значень кінематичної в'язкості за методикою ДСТУ ГОСТ 25371:2006 (HOST 5985, 1979). Лужне число отримали з використанням автоматичного титратора Metrohm 905 згідно 3 методикою ДСТУ 5094:2008 (DSTU ISO 12937, 2013). Кислотне числа от- 
римали з використанням цього ж титратора згідно 3 методикою ГОСТ 5985-79 (Syrojedov et al., 2016). Вміст води отримали 3 використанням автоматичного титратора Metrohm 890 згідно $з$ ДСТУ ISO 12937:2012 (Shkolnikov, 1989).

Для контролю хімічного очищення зразків використовували ваговий метод. Спочатку послідовно зважували забруднені деталі на електричних вагах BTU 210 та аналітичних вагах АДВ-200М, потім їх витримували за періодичного струшування у приготованих розчинниках та розчинах, ретельно промивали у воді з температурою до $50{ }^{\circ} \mathrm{C}$, а потім - у холодній. Забруднювачами поверхні були солідол і мастильно-охолоджувальна рідина (МОР) Укрінол-4. Вибір цих речовин обгрунтували необхідністю порівняти здатність розчинників взаємодіяти з сумішшю мінеральної оливи й кальцієвого мила вищих жирних кислот (солідол) і водним розчином мінеральної оливи, емульгаторів та інгібіторів корозії (Укрінол-4). Як розчинники використовували гексан $\mathrm{C}_{6} \mathrm{H}_{14}$, октан $\mathrm{C}_{8} \mathrm{H}_{18}$, бензен $\mathrm{C}_{6} \mathrm{H}_{6}$, трихлорметан $\mathrm{CHCl}_{3}$, тетрахлорметан $\mathrm{CCl}_{4}$, дихлоретан $\mathrm{C}_{2} \mathrm{H}_{4} \mathrm{Cl}_{2}$, етанол $\mathrm{C}_{2} \mathrm{H}_{5} \mathrm{OH}$, ізобутанол $\mathrm{C}_{4} \mathrm{H}_{9} \mathrm{OH}$, етилетаноат $\mathrm{C}_{2} \mathrm{H}_{5} \mathrm{OCOCH}_{3}$, натрій гідроксид $\mathrm{NaOH}$ розведений $(2 \mathrm{M})$ i концентрований $(6 \mathrm{M})$, хлоридну кислоту $\mathrm{HCl}$ розведену (2M) та концентровану (6M). Висушували зразки у сушильній шафі VIOLA 2B-151 і після охолодження до кімнатної температури зважували. Чистоту зразків перевіряли за методом змочування (спостерігали однорідну плівку води на чистих деталях і розрив плівки на неповністю очищених деталях). Для гартованих зразків використовували метод розпилення фуксину. На очищену поверхню розпилювали розчин барвника фуксину 3 додаванням фенолу та гліцеролу. Сліди олив залишали на зразку яскраво-червоні плями. Перед висушуванням барвник змивали гарячою водою.

Результати дослідження та їх обговорення. Під час зберігання, транспортування, а також під час роботи верстатів та іншого технологічного обладнання оливи зазнають впливу кисню повітря, що призводить до зміни їхнього хімічного складу та фізико-хімічних властивостей. Ці зміни, спричиняють забруднення поверхні деталей, які безпосередньо з ними контактують. Схильність олив до окиснення, швидкість цього процесу та хімічний склад продуктів окиснення залежать від природи оливи, температури, тиску повітря, площі поверхні, що безпосередньо контактує з повітрям, тривалості використання оливи. Практично всі оливи після тривалого перебування на світлі та контакту з киснем повітря починають темніти внаслідок утворення в них смол та інших продуктів окиснення. Окиснення сповільнюється у темноті та за розсіяного світла.

Зі всіх вуглеводнів, що входять до складу олив, найбільш стійкими до окиснення $є$ ароматичні, менш стійкими є алкени й алкани (Mang \& Dresel, 2017). Найбільше окиснюються киснем повітря парафінові вуглеводні. Після очищення в оливах залишається незначна кількість смол, які є природними антиокисниками. Внаслідок окиснення вони перетворюються в нерозчинні продукти - асфальтени і карбени. За кімнатної температури та атмосферного тиску окиснення олив відбувається доволі повільно, з підвищенням температури швидкість процесу значно прискорюється. За температури вище від $270 \ldots 300{ }^{\circ} \mathrm{C}$, поряд 3 процесами окиснення, починається процес розкладання вуглевод- нів із виділенням частинок сажі. Підвищення тиску прискорює ці процеси. У тонких плівках оливи швидко окиснюються і на поверхні деталей відкладаються смоли та асфальтени.

Вагому роль у прискоренні процесу окиснення відіграють каталізатори, найкращими з яких є $\mathrm{Fe}, \mathrm{Cu}, \mathrm{Ni}, \mathrm{Pb}$, Mn, Zn як у металічному стані, так і у вигляді сполук, тоді як Al, Sn практично не прискорюють процес, а деякі їхні солі навіть $є$ інгібіторами. Окиснення олив прискорюється і солями металів із нафтеновими кислотами, які входять до складу олив. Швидкість окисновідновних процесів у оливах зростає і за наявності води, оскільки вона активує багато каталізаторів (Shkolnikov, 1989).

Під час роботи верстатів і технологічного обладнання в оливах поряд із первинними процесами окисненнявідновлення та розкладу з утворенням органічних кислот, альдегідів, спиртів, фенолів тощо перебігають вторинні процеси полімеризації та конденсації з утворенням смолистих речовин, полімерів, лаків тощо. Внаслідок окиснення олив одержують $8 \ldots 18 \%$ кислотних сполук, 39...57\% смол і $4 \ldots 11 \%$ інших продуктів (Mang \& Dresel, 2017).

Залежно від здатності утворювати кислі чи нейтральні продукти, перебіг процесів окиснення та окиснювальної полімеризації здійснюється двома шляхами:

1) вуглеводневі сполуки $\rightarrow$ пероксидні сполуки $\rightarrow$ кислоти $\rightarrow$ оксикислоти $\rightarrow$ естоліди $\rightarrow$ асфальтогенові кислоти;

2 ) вуглеводневі сполуки $\rightarrow$ пероксидні сполуки $\rightarrow$ смоли $\rightarrow$ асфальтени $\rightarrow$ карбени $\rightarrow$ карбоїди.

Продукти глибокого окиснення та результати перебігу фізико-хімічних процесів - оксикислоти, асфальтогенові кислоти, асфальтени, карбони, карбоїди - на відміну від смол і кислот не розчиняються в оливі, тому випадають в осад або утворюють колоїдні розчини. Такі шламоподібні продукти відкладаються на внутрішніх поверхнях в оливопроводах і порушують циркуляцію олив. Для запобігання цьому проводять періодичний аналіз олив, який може охоплювати різну кількість параметрів. Найчастіше визначають кислотне та лужне число, кінематичну в'язкість та індекс в'язкості, рівень окиснення і нітрування, вміст води та сажі. За точнішому аналізу визначають вміст в оливі певних хімічних елементів.

Найбільш істотним критерієм придатності олив є кислотне число, причому важливо знати не тільки його величину, а й типи утворених кислот з огляду на те, що низькомолекулярні кислоти характеризуються більшою корозійною активністю, ніж високомолекулярні. У безводній оливі навіть низькомолекулярні кислоти не становлять значної небезпеки, за наявності води ця загроза зростає у багато разів. Тому підвищення кислотного числа, як і здатність олив утворювати низькотемпературний шлам (асфальтени, карбони, карбоїди, солі Феруму, Купруму та інших металів 3 нафтеновими та карбоновими кислотами), становить потенційну небезпеку їх забруднення.

Наявність на поверхні деталі залишків оливи є небезпечною щодо подальшого використання виробу як підкладки для напилення вакуумних йонно-плазмових покриттів. Ця небезпека зростає у рази, якщо сама відпрацьована олива містить залишки сторонніх речовин, 
що утворились у процесі експлуатації. Тому важливо знати якісний та кількісний склади забруднювальних речовин, щоб визначити реагенти для їхньої нейтралізації. Дослідження фізико-хімічних властивостей та визначення вмісту сторонніх продуктів в оливах класу HLP (згідно з DIN 51 524-2) для гідросистем і для напрямних верстатів провели згідно з методикою, наведеною вище. Результати цих досліджень і порівняння ІЧ- спектрів свіжої та вживаної олив (рисунок) показали (табл. 1), що в процесі роботи олива окиснюється, про що свідчать зміна кольору, зростання кислотного числа. Дещо знижується температура спалаху та зростає температура застигання, зменшується кінематична в'язкість. Найбільше процес експлуатації впливає на зростання кислотного числа (у три рази) та вмісту води (в дев'ять разів).

Табл. 1. Порівняння результатів випробування свіжої та відпрацьованої олив

\begin{tabular}{|c|c|c|c|c|c|c|c|}
\hline Параметр & $\begin{array}{c}\text { Свіжа олива для нап- } \\
\text { рямних верстатів }\end{array}$ & $\begin{array}{c}\text { Свіжа олива для гід- } \\
\text { росистем }\end{array}$ & \multicolumn{2}{|c|}{$\begin{array}{l}\text { Відпрацьована олива } \\
\text { для гідросистем }\end{array}$} & \multicolumn{3}{|c|}{$\begin{array}{c}\text { Частка погіршення } \\
\text { показників, \% }\end{array}$} \\
\hline Густина за $15^{\circ} \mathrm{C}, \kappa \Gamma / \mathrm{m}^{3}$ & 888 & 885,1 & \multicolumn{2}{|c|}{884,3} & \multicolumn{3}{|c|}{0,1} \\
\hline Кінематична в'язкість $3 \mathrm{a} 40^{\circ} \mathrm{C}, \mathrm{mm}^{2} / \mathrm{c}$ & 69,75 & 71,38 & \multicolumn{2}{|c|}{68,12} & \multicolumn{3}{|c|}{4,6} \\
\hline Кінематична в'язкість за $100^{\circ} \mathrm{C}, \mathrm{mm}^{2} / \mathrm{c}$ & 8,86 & 9,00 & \multicolumn{2}{|c|}{8,65} & \multicolumn{3}{|c|}{3,9} \\
\hline Індекс в'язкості & 99 & 100 & \multicolumn{2}{|l|}{98} & \multicolumn{3}{|c|}{2} \\
\hline Кислотне число ТАN, мг КОН/Г & 0,43 & 0,67 & \multicolumn{2}{|c|}{1,97} & \multicolumn{3}{|c|}{194} \\
\hline Колір, прозорість & жовтий, прозора & жовтий, прозора & \multicolumn{2}{|c|}{$\begin{array}{c}\text { темно-коричнева, } \\
\text { непрозора }\end{array}$} & & & \\
\hline Температура застигання, ${ }^{\circ} \mathrm{C}$ & & -30 & \multicolumn{2}{|c|}{-26} & \multicolumn{3}{|c|}{13,3} \\
\hline \multirow{2}{*}{$\begin{array}{l}\text { Температура спалаху, }{ }^{\circ} \mathrm{C} \\
\text { Клас чистоти }\end{array}$} & & 222 & \multicolumn{2}{|l|}{217} & \multicolumn{3}{|c|}{2,3} \\
\hline & 6 & 7 & \multicolumn{2}{|l|}{9} & & & \\
\hline Вміст води, \% & 0,01 & 0,01 & 0,09 & & \multicolumn{3}{|c|}{800} \\
\hline \multirow[t]{2}{*}{$\sqrt[5]{-}$} & \multirow{2}{*}{\begin{tabular}{|l|} 
- Свіжа гідравлічна олива \\
- Вживана гідравлічна олива
\end{tabular}} & $12 \begin{array}{l}\begin{array}{l}\mathrm{HCl} \text { po3в. } \\
(2 \mathrm{M})\end{array} \\
\end{array}$ & 5,7083 & \multicolumn{2}{|c|}{5,6995} & 0,0089 & 0,16 \\
\hline & & \begin{tabular}{|l|l}
13 & $\begin{array}{l}\mathrm{HCl} \text { конц. } \\
(6 \mathrm{M})\end{array}$ \\
\end{tabular} & 5,7162 & \multicolumn{2}{|c|}{5,6973} & 0,0189 & 0,33 \\
\hline
\end{tabular}

Табл. 3. Результати хімічного очищення зразків, оброблених МОР Укрінол-4

\begin{tabular}{|c|c|c|c|c|c|}
\hline \multirow[b]{2}{*}{$\begin{array}{l}\text { № } \\
\text { 3/ }\end{array}$} & \multirow[b]{2}{*}{ Розчинник } & \multicolumn{2}{|c|}{ Маса зразка } & \multirow[b]{2}{*}{$\Delta m, \Gamma$} & \multirow{2}{*}{$\begin{array}{c}\Delta m / m_{1} \\
\%\end{array}$} \\
\hline & & $\begin{array}{l}\text { до проми- } \\
\text { вання } m_{1}, \Gamma\end{array}$ & \begin{tabular}{|c|} 
після проми- \\
вання $m_{2}, \Gamma$
\end{tabular} & & \\
\hline 1 & Гексан $\mathrm{C}_{6} \mathrm{H}_{14}$ & 8,9789 & 8,9407 & 0,0382 & 0,43 \\
\hline 2 & Октан $\mathrm{C}_{8} \mathrm{H}_{18}$ & 9,0029 & 8,9859 & 0,0170 & 0,19 \\
\hline 3 & Бензен $\mathrm{C}_{6} \mathrm{H}_{6}$ & 8,7202 & 8,6947 & 0,0255 & 0,29 \\
\hline 4 & $\begin{array}{l}\text { Трихлорметан } \\
\mathrm{CHCl}_{3}\end{array}$ & 8,7212 & 8,7063 & 0,0149 & 0,17 \\
\hline 5 & $\begin{array}{l}\text { Дихлоретан } \\
\mathrm{C}_{2} \mathrm{H}_{4} \mathrm{Cl}_{2} \\
\end{array}$ & 8,9119 & 8,8739 & 0,0380 & 0,43 \\
\hline 6 & $\begin{array}{l}\text { Тетрахлорме- } \\
\text { тан } \mathrm{CCl}_{4}\end{array}$ & 5,6619 & 5,6318 & 0,0301 & 0,53 \\
\hline 7 & $\begin{array}{l}\text { Етанол } \\
\mathrm{C}_{2} \mathrm{H}_{5} \mathrm{OH} \\
\end{array}$ & 5,9315 & 5,9039 & 0,0276 & 0,47 \\
\hline 8 & $\begin{array}{l}\text { Ізобутанол } \\
\mathrm{C}_{4} \mathrm{H}_{9} \mathrm{OH}\end{array}$ & 8,5209 & 8,4998 & 0,0211 & 0,25 \\
\hline 9 & $\begin{array}{l}\text { Етилетаноат } \\
\mathrm{C}_{2} \mathrm{H}_{5} \mathrm{OCOCH}_{3} \\
\end{array}$ & 8,3575 & 8,3436 & 0,0139 & 0,17 \\
\hline 10 & $\begin{array}{l}\mathrm{NaOH} \text { розв. } \\
(2 \mathrm{M})\end{array}$ & 8,6392 & 8,6243 & 0,0149 & 0,17 \\
\hline 11 & $\begin{array}{l}\mathrm{NaOH} \text { конц. } \\
(6 \mathrm{M})\end{array}$ & 8,8789 & 8,8546 & 0,0243 & 0,27 \\
\hline
\end{tabular}

Висновки. Для зразків, оброблених солідолом, найкращий результат продемонстрували неполярний розчинник октан $\mathrm{C}_{8} \mathrm{H}_{18} \mathrm{i}$ слабкополярний розчинник етилетаноат $\mathrm{C}_{2} \mathrm{H}_{5} \mathrm{OCOCH}_{3}$, для яких втрата маси перевищила $1 \%$. Хороший ступінь очищення із втратою маси більше ніж $0,5 \%$ виявили також неполярні розчинники гексан $\mathrm{C}_{6} \mathrm{H}_{14}$ та бензен $\mathrm{C}_{6} \mathrm{H}_{6}$ та хлорозаміщені вуглеводні. Найкращим серед них виявився трихлорметан $\mathrm{CHCl}_{3}$ та дихлоретан $\mathrm{C}_{2} \mathrm{H}_{4} \mathrm{Cl}_{2}$, трохи гірший показник в інертного розчинника тетрахлорметану $\mathrm{CCl}_{4}$. Характерним для неполярних розчинників $\epsilon$ те, що ступінь очищення збільшувався зі зростанням молярної маси розчинника та насичення Гідрогеном, а для хлорозаміщених вуглеводнів - із зростанням насичення Хлором. Найкращі результати очищення зі спиртів виявили в 
ізобутанолу $\mathrm{C}_{4} \mathrm{H}_{9} \mathrm{OH}$. Невідмитими залишилися деталі в лужних та кислих розчинах та в етанолі $\mathrm{C}_{2} \mathrm{H}_{5} \mathrm{OH}$, де візуально спостерігали розриви плівок води та сліди висушених олив. Тому полярність розчинника для таких зразків є вирішальною. Зразки, оброблені МОР Укрінол-4, більшою чи меншою мірою відмивалися всіма розчинами, візуально слідів олив не виявили під час жодного спостереження. Найкращий результат виявили для таких розчинників: тетрахлорметану $\mathrm{CCl}_{4}$, етанолу $\mathrm{C}_{2} \mathrm{H}_{5} \mathrm{OH}$, гексану $\mathrm{C}_{6} \mathrm{H}_{14}$ та дихлоретану $\mathrm{C}_{2} \mathrm{H}_{4} \mathrm{Cl}_{2}$. Очевидно, що тут вагомим $є$ внесок ПАР і присадок, що присутні у складі МОР.

Загалом, аналізуючи вплив різних класів розчинників на ступінь очищення поверхні деталей, можна зробити висновок про те, що здатність до очищення зростає у такій послідовності: лужні та кислі водні розчини $\rightarrow$ спирти $\rightarrow$ хлорозаміщені вуглеводні $\rightarrow$ неполярні та слабкополярні розчинники.

Встановлено, що в процесі роботи олива окиснюється, знижується температура спалаху та зростає температура застигання, зменшується кінематична в'язкість. Найбільше процес експлуатації впливає на зростання кислотного числа (у три рази) та вмісту води (в дев'ять разів).

\section{Перелік використаних джерел}

ASTM E2412. (2004). Standard Practice for Condition Monitoring of In-Service Lubricants by Trend Analysis Using Fourier Transform Infrared (FT-IR) Spectrometry: American Society for Testing and Materials.

DSTU 5094:2008. (2009). Petroleum products. Oils lubricant, additives and packages of additives. Test method for base number by potentiometric titration, from 01 Mart 2009. Kyiv: State Committee of Ukraine for Technical Regulation and Consumer Policy, 14 p. [In Ukrainian].

DSTU HOST 25371:2006. (2006). Petroleum products. Calculation of the viscosity index by kinematic viscosity, from 01 Mart 2007. Kyiv: State Committee of Ukraine for Technical Regulation and Consumer Policy, 7 p. [In Ukrainian].

DSTU HOST 33-2003. (2003). Petroleum products. Transparent and opaque liquids. Determination of kinematic viscosity and calculati- on of dynamic viscosity, from 01 Jul 2003. Kyiv: State Committee of Ukraine for Technical Regulation and Consumer Policy, 27 p. [In Ukrainian].

DSTU ISO 12937:2012. (2013). Petroleum products. Determination of water-Coulometric Karl Fisher titration method (ISO 12937:2000, IDT), from 01 May 2013. Kyiv: Ministry of Economic Development and Trade of Ukraine, $15 \mathrm{p}$. [In Ukrainian].

Dubinin, G. V., et al. (2012). Application of ultrasonic treatment to surface cleaning of additional wire for argon-arc welding. Welding Production, 2, 33-36. [In Russian].

Hasiy, O. B. (2008). The technology of products cleansing before vacuum ion-plasma coatings sputtering. Scientific Bulletin of UNFU, 18(4), 95-98. [In Ukrainian].

HOST 5985-79. (1979). Petroleum rhoducts. Method for determination of acidity and acid number (with Changes № 1, 2, with Amendment), from 30 Mart 1979. Moscow: State Committee for Standardization, 6 p. [In Ukrainian].

Maksimov, V. G., \& Grigorova, T. M. (2007). Fundamentals of calculation, design and operation of technological equipment. Odesa: Science and Technology, 184 p. [In Ukrainian].

Mang, T., \& Dresel, W. (2017). Lubricants and Lubrication. Weinheim: Wiley-VCH Verlag GmbH \& Co. KGaA, 1203 p.

Savuliak, V. I., \& Osadchuk, A. Yu. (2004). Manual electric arc welding. Vinnytsa: VNTU, 130 p. [In Ukrainian].

Shevchenko, L. A., Zelinskaja, V. V., \& Zhupinskaja, L. T. (2009). Research and determination of technological parameters of cleaning of surface became low temperature plasma from contaminations. Fundamental and applied problems of ferrous metallurgy: collection of scientific papers of Iron and Steel Institute of the NAS of Ukraine, 20, 188-195. Dnipropetrovsk. [In Ukrainian, Russian].

Shkolnikov, V. M. (Ed.). (1989). Fuels, lubricants, technical fluids. Assortment and application: reference edition. Moscow: Chemistry, 432 p. [In Russian].

Smirnov, I. V. (2012). Reconditioning of machine parts and structures. Kyiv: NTUU "Igor Sikorsky Kyiv Polytechnic Institute", 147 p. [In Ukrainian].

Syrojedov, N. E., Galko, S. A., Sharykin, F. E., \& Muratkhanov, N. A. (2016). Watering of synthetic oils for aircraft. Civil avition high technologies, 19(3), 74-79. [In Russian].

Vasiltsov, A. S., \& Podvezenny, V. N. (2011). The mechanism for removing carbon dioxide from hydrocarbon contaminants from structural materials of tanks. Bulletin of the KSTU, 5, 71-74. [In Russian].

O. B. Hasiy, M. F. Fedyna, L. V. Salapak

Ukrainian National Forestry University, Lviv, Ukraine

\section{EFFECT OF SOLVENTS CHEMICAL COMPOSITION ON THE DEGREE OF SURFACE CLEANING BEFORE EVAPORATION OF ION-PLASMA COATINGS}

The article presents the results of studies of the influence of different classes of solvents on oil-containing contaminants on the surface of carbon steel details before applying of ion-plasma coatings. The solvents used were as follows: $\mathrm{C}_{6} \mathrm{H}_{14}, \mathrm{C}_{8} \mathrm{H}_{18}, \mathrm{C}_{6} \mathrm{H}_{6}$, $\mathrm{CHCl}_{3}, \mathrm{CCl}_{4}, \mathrm{C}_{2} \mathrm{H}_{4} \mathrm{Cl}_{2}, \mathrm{C}_{2} \mathrm{H}_{5} \mathrm{OH}, \mathrm{C}_{4} \mathrm{H}_{9} \mathrm{OH}, \mathrm{C}_{2} \mathrm{H}_{5} \mathrm{OCOCH} \mathrm{H}_{3}, \mathrm{NaOH}, \mathrm{HCl}$. The surface pollutants were solidol and lubricant-cooling liquid (LCL) Ukrinol-4. For solididol-treated specimens, the best result was recorded in a non-polar $\mathrm{C}_{8} \mathrm{H}_{18}$ octane solvent and a lowpolar $\mathrm{C}_{2} \mathrm{H}_{5} \mathrm{OCOCH}_{3}$ ethylethanoate solvent for which the weight loss exceeded $1 \%$. Non-polar solvents of hexane $\mathrm{C}_{6} \mathrm{H}_{14}$, benzene $\mathrm{C}_{6} \mathrm{H}_{6}$ and chloro substituted hydrocarbons also showed a good degree of purification with a weight loss of more than $0.5 \%$. Most preferred among these are $\mathrm{CHCl}_{3}$ trichloromethane and $\mathrm{C}_{2} \mathrm{H}_{4} \mathrm{Cl}_{2}$ dichloroethane, a slightly worse indicator in $\mathrm{CCl}_{4}$ tetrachloromethane inert solvent. The degree of purification by non-polar solvents improved with increasing molar mass of the solvent and saturation with hydrogen, and with chloro-substituted hydrocarbons - with increasing saturation with Chlorine. The best results of alcohol purification were found in isobutanol $\mathrm{C}_{4} \mathrm{H}_{9} \mathrm{OH}$. The details in alkaline and acidic solutions and in ethanol $\mathrm{C}_{2} \mathrm{H}_{5} \mathrm{OH}$ remained undetected. Specimens treated with the LCL of Ukrinol-4 were washed with all solvents, no traces of oils were detected visually at any observation. The best result was found for the following solvents: $\mathrm{CCl}_{4}$ tetrachloromethane, $\mathrm{C}_{2} \mathrm{H}_{5} \mathrm{OH}$ ethanol, $\mathrm{C}_{6} \mathrm{H}_{14}$ hexane and $\mathrm{C}_{2} \mathrm{H}_{4} \mathrm{Cl}_{2}$ dichloroethane, which indicates a significant surface-active substances (SAS) contribution and additives in the LCL composition. The ability to purify increases in the following order: alkaline and acidic solutions $\rightarrow$ alcohols $\rightarrow$ chloro substituted hydrocarbons $\rightarrow$ non-polar and low-polar solvents. Physicochemical properties were investigated and the content of by-products in HLP oils for hydraulic systems and machine guides was determined. The IR spectrum of fresh and used oils have been compared. It is established that during the operation oil oxidizes. Most of the exploitation process had an increase in acid number (three times) and water content (nine times).

Keywords: mineral oil; calcium soaps; lubricant-cooling liquid; surface-active substances; infrared spectrum; acid number. 